\title{
Natural Food Preservation Based on Randu Leaf Extract (Ceiba pentadra) and White Onion (Allium sativum) Extract on The Intensity of Bacterial Series In Tomato and Bakso Beef
}

\author{
Muhammad Syarif Hidayat ${ }^{1}$, , Retno Sri Iswari ${ }^{2}$, Siti Harnina Bintari ${ }^{2}$ \\ ${ }^{1}$ Mahasiswa Pascasarjana; ${ }^{2}$ Dosen Pascasarjana Universitas Negeri Semarang \\ Kampus Pascasarjana UNNES Jl. Kelud Utara III Semarang 50237 \\ Email*: syarifh14320029@students.unnes.ac.id
}

\begin{abstract}
The purpose of this study was to determine the effect of kapok leaf extract and garlic extract tubers effectively inhibit bacteria in tomatoes and beef meatballs. The research design uses a completely randomized design (CRD) which consists of one factor, namely food preservatives. Tomato and beef meatballs samples were immersed in kapok leaf extract and garlic bulb extract with different concentrations, namely $0,50 \%$ and 50\%, 100\% garlic bulb extract and 100\% kapok leaf extract for 15 minutes. Then the samples were stored at room temperature ranging from 22-31 degrees centigrade for 5 days. The results showed that the kapok leaf extract and garlic tuber extract effectively inhibited inhibiting bacteria.
\end{abstract}

Keywords: food preservatives, kapok leaves, garlic bulbs.

\section{INTRODUCTION}

Humans need food in their lives both for growth and to maintain their lives. Humans are healthy because of their food and humans can also get sick because their food and lifestyle also determine a person's health. Food in general is easily damaged due to water content and organic compounds so that it is prone to decay.

Nowadays, human food has been preserved using chemical preservatives which are very dangerous for health. This is because food is very easily damaged, especially meat, milk and eggs. The food has a high nutritional value so that if stored it will be easily polluted and damaged, therefore the food preservation system has been widely used ranging from cooling, freezing to the use of preservatives added to food so that it lasts longer when stored.

Preservatives now have many types, both chemicals and natural ingredients such as spices, even preservatives that are not for food, for example formalin is widely used in foods such as noodles, meatballs and fish, by irresponsible elements. This chemical preservative is dangerous if swallowed by humans so that it is necessary for awareness from various parties to use natural ingredients that are cheap and easily available in nature. Examples of such are the leaves and cotton bulbs of garlic.

Researchers used kapok leaf extract and garlic tuber extract because both of them have antiviral bioactive substances. The leaves extract has Flavonoid which plays an important role in the biochemistry and physiology of plants, including functioning as an enzyme inhibitor. Flavonoids in plants also function to regulate growth, regulate photosynthesis, regulate the action of antibacterial, antiviral, and antisangga (Harborne, 1996). Flavonoid compounds show inhibitory effects on various bacteria such as Vibrio cholera, Streptococcus mutans, Shigella, (Omojate et al., 2014). While the Garlic bulb extract contains a substance called alicin as an antimicrobial and antiviral substance and contains antioxidants that can maintain body health. The advantages of garlic bulb extract can be used as research material to be more open to the efficacy of garlic deeper, especially in terms of preserving food derived from meat.

Livestock products such as meatballs are very easily damaged if not preserved. Meatball sellers sometimes do not preserve meatballs when they are sold so that the contamination of meatballs, especially bacteria, is very easy to enter and decompose the meatballs. It is known that E. coli bacteria can contaminate meatballs, making it less safe to consume because it causes diarrhea. It is necessary to have an alternative material from natural ingredients so that the meatballs can last longer when stored at room temperature is also safe for consumption.

Tomato is a fruit vegetable plant that is needed by humans to make ends meet. This is due to the nutritional content of tomatoes consisting of vitamins and minerals which are very useful for maintaining health and preventing disease (Surtinah, 2007). One type of vegetable that is very well known and is loved by most of the people in this society has a sweet and sour taste and can provide freshness to the body. Lots of uses of tomatoes, among others, as a vegetable seasoning, fresh 
vegetables, preserved food (tomato sauce), fresh fruit, or drinks (juice) (Tim Writer PS, 2004). The cause of damage to tomatoes is E. carotovora. The initial symptoms seen are small wet sores, which increase in diameter and depth. The infected area becomes soft while the surface color fades. The tissue in the infected area becomes creamy and thin, then becomes destroyed. The outer surface will look intact but the inside changes to become soft, runny, and brown (Agrios, 1997).

\section{METHOD}

Making kapok leaf extract and garlic bulb extract using maceration process.

\section{Making Garlic Bulbs Extract}

Peeled garlic (500 grams) in a blender, then the results of the blender squeezed with a cloth. The results of the juice were centrifuged $2 \mathrm{x}$ with a speed of 10,000 rpm. Supernatants were collected and extraction results were obtained at $100 \%$.

\section{Making Randu Leaf Extract}

1. Leaves are washed and then drained until dry.

2. Leaves are cut into small pieces, then put in the oven (temperature $30-40^{\circ} \mathrm{C}$ ) until dry.

3. Leaves are blended, then sifted to produce fine powder.

4. Extracts of 200 gram fine powder of leaves of kapok leaves for $3 \times 24$ hours using $600 \mathrm{ml}$ of ethanol (96\%) solvent.

5. Thicken the extract using a rotary evaporator at a temperature of $50^{\circ} \mathrm{C}$ at a speed of $8 \mathrm{rpm}$.

6. Put thick extract into the oven at a temperature of 30$40^{\circ} \mathrm{C}$, produced powder.

\section{RESULTS AND DISCUSSION}

After storing the samples for 5 days at room temperature, the results were significantly different in the treatment of the samples and administration of extracts of $50 \%$ and $50 \%$ between the leaves of the kapok and the tubers of garlic.

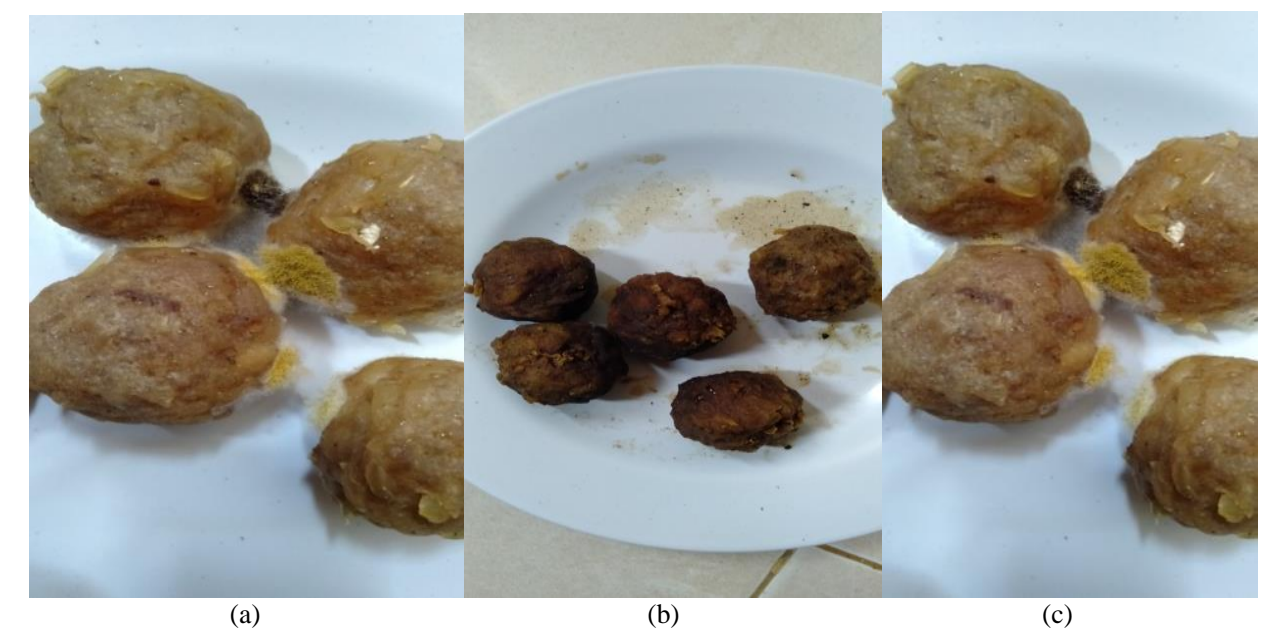

Figure 1. Results in the treatment of extracts of 50\% and 50\% between the leaves of the kapok and the tubers of garlic; and $100 \%$. Control (a); $50 \%$ and $50 \%$ (b); and $100 \%$ for each (c).

The control of meatballs has been attacked by bacteria on the 3rd day, the administration of $50 \%$ concentration of kapok leaf extract and garlic tuber extract of meatballs still looks safe and suppresses bacterial growth, for each - $100 \%$ still influential but not so effective so bacterial growth is still visible. While on tomatoes on day 5 there is still no sign of bacterial growth as well as tomatoes which are given $100 \%$ and $50 \%$ treatment are still safe.

\section{CONCLUSION}

The best treatment was obtained with the addition of $50 \%$ of the kapok leaf extract and garlic tuber extract.
Because it effectively suppresses bacterial growth in tomatoes and beef meatballs.

\section{REFERENCES}

Agrios, G. N. (1997). Plant pathology (4rd ed.). New York: Academic Press.

Branen, L.A. and P.M. Davidson. 1993. Antimicrobials in Foods. Marcel Dekker., Inc. New York. 675 pp.

Davidson, P. Michael., Branen A. L., 2005. Antimicrobial's in food. Prancis.CRC Press.

Dinas Pertanian Provinsi Sulawesi Tengah. (2013). Data sayuran dan buah-buahan semusim tahun 2013. Palu: Dinas Pertanian. 
Elliot middleton, J.R., ChittanKandaswani and Theorides, TC., 2000, The Effect of Plant Flavonoids on Mammalian Cells: Implication for Inflamation, Heart Disease and Cancer The American Society for Pharmacology and experimental Theurapetics, Vol 52 No 4, 47/867/401, Printed in USA. Hal 709,713 .

Friday, E. T., James, O., Olusegun, O., \& Gabriel, A. (2011). Investigations on the nutritional and medicinal potentials of Ceibapentandra leaf: A common vegetable in Nigeria. International Journal of Plant Physiology and Biochemistry Vol. 3(6), 95-101. Dipetik Januari 10, 2016, dari http://www.academicjournals.org/article/article1380033540_F riday et al.pdf.

Harborne, J.B, 1996, Metode Fitokimia, Cetakan II, diterjemahkan oleh Kosasih Padma Winata dan Iwang Soediro, ITB Press, Bandung, 70-72.

Hernawan, U.E., dan Setyawan, A. D., Senyawa Organosulfur Bawang Putih (Allium sativum) dan Aktivitas Biologinya, Biofarmasi, Vol 1 No 2, 2003, hlm 74.
Keko Hori, Maxima E. Flavier, Shigenori Kuga, Thi Bach Tuyet, \& Kenji Liyama. (2000). Excellent Oil Absorbent Kapok (Ciebapentandra L) Fiber: Fiber Stucture, Chemical Characteristics, and application. J Wood Sci 46.401-404.

KPH Kendal. (2011). Monitoring \&Evaluasi Jenis Tanaman Rimba Eksotik. Diakses dari http://www.kphkendal.com/files/eksotik.pdf padaTanggal 26 Oktober 2014 Jam 19:38 WIB.

Lawrie R A. 2003. Ilmu Daging. Penerjemah Aminuddin Parakkasi. UI Press. Jakarta.

Soeparno. 2005. Ilmu dan Teknologi Daging. Gadjah Mada University Press. Yogyakarta.

Surtinah. (2007). Kajian tentang hubungan pertumbuhan vegetative dengan produksi tanaman tomat (Lycopersicum esculentum, mill). Jurnal Ilmiah Pertanian, 4(1), 1-9.

Tim Penulis PS. (2004). Tomat pembudidayaan secara komersial. Jakarta: Penebar Swadaya. 
THIS PAGE INTENTIONALLY LEFT BLANK 